\title{
Chapter 13 \\ Habitat Modification and Coastal \\ Protection by Ecosystem-Engineering Reef-Building Bivalves
}

\author{
Tom Ysebaert, Brenda Walles, Judy Haner, and Boze Hancock
}

\begin{abstract}
Reef-building bivalves like oysters and mussels are conspicuous ecosystem engineers in intertidal and subtidal coastal environments. By forming complex, three-dimensional structures on top of the sediment surface, epibenthic bivalve reefs exert strong bio-physical interactions, thereby influencing local hydro- and morphodynamics as well as surrounding habitats and associated species. The spatial impact of the ecosystem engineering effects of reef-building bivalves is much larger than the size of the reef. By influencing hydrodynamics oysters and mussels modify the sedimentary environment far beyond the boundaries of the reef, affecting morphological and ecological processes up to several hundreds of meters.

Being key-stone species in many coastal environments, reef-building bivalves are increasingly recognized for their role in delivering important ecosystem services that serve human wellbeing. Here we focus on two services, namely the regulating service coastal protection (coastal erosion prevention, shoreline stabilization) and the supporting habitat for species service (enhancement of biodiversity and diversification of the landscape). Due to their wave dampening effects, reef-building bivalve reefs are increasingly used for shoreline protection and erosion control along eroding coastlines, as an alternative to artificial shoreline hardening. The
\end{abstract}

T. Ysebaert $(\square)$

Wagenungen UR, Wageningen Marine Research, Wageningen University \& Research, AB, Yerseke, The Netherlands

NIOZ Yerseke, Royal Netherlands Institute for Sea Research and Utrecht University,

AC, Yerseke, The Netherlands

e-mail: tom.ysebaert@wur.nl

B. Walles

Wageningen UR, Wageningen Marine Research, Yerseke, The Netherlands

e-mail: brenda.walles@wur.nl

J. Haner

The Nature Conservancy, Coastal Programs Office, Mobile, AL, USA

B. Hancock

The Nature Conservancy, URI Graduate School of Oceanography, Narragansett, RI, USA

e-mail: bhancock@TNC.ORG 
facilitative interactions at long-distances of bivalve reefs provide biodiversity benefits and more specifically facilitate or protect other valuable habitats such as intertidal flats, sea grasses, saltmarshes and mangroves.

Two case studies are used to demonstrate how bivalve reefs can be restored or constructed for shoreline protection and erosion control, thereby focusing on oyster reefs: (1) Oyster reefs for shoreline protection in coastal Alabama, USA, and (2) Oyster reefs as protection against tidal flat erosion, Oosterschelde, The Netherlands.

It is argued that bivalve reefs should be promoted as nature-based solutions that provide biodiversity benefits and coastal protection and help in climate change mitigation and adaptation. In order to successfully restore these habitats practitioners should consider a general framework in which habitat requirements, environmental setting and long-distance interdependence between habitats are mutually considered.

\begin{abstract}
Chinese 牡蚛和贻贝这类可以形成贝礁的双壳贝类是潮间带和潮 下带海岸环境中出色的生态系统工程师。通过在沉积物表面上形成复杂的三 维结构, 浅海双壳贝礁发挥着强大的生物一物理作用, 并影响当地的水文和形 态动力学以及周围的生境和相关物种。造礁双壳类生态系统工程的空间影响 远大于生物贝礁的本身尺度。牡蚛和贻贝可以通过影响贝礁体周边的水动力 状态从而改变离贝礁本体较远区域的沉积环境, 他们对底质形态和生态过程 的影响范围可达礁体周边数百米。

作为诸多沿海环境中的关键物种, 造礁双壳贝类担负着非常重要的生态系 统服务功能, 因此越来越受到人们的重视, 。本文中我们着重于双壳贝类的两 个生态服务, 即海岸带保护的调节服务 (预防海岸侵蚀, 稳固海岸线) 和栖息地 维护服务 (增强生物多样性和景观多样化)。作为人造海岸线硬化的一种替代 方案, 双壳贝礁越来越多地被用于易受波浪冲刷侵蚀岸线地带的防护。大规 模的双壳贝礁有助于增加海岸带的生物多样性, 且更好地保护了潮间带滩涂, 海草, 盐沼和红树林等宝贵的栖息地。

本文利用两个案例研究说明如何恢复或建造双壳贝礁以保护海岸线和控 制侵蚀, 以牡蚛礁为例：(1) 在美国沿海阿拉巴马州用于海岸线保护的牡蚛 礁; (2) 在荷兰的东斯海尔德水道应对潮滩侵蚀的牡蚛礁。

一些观点认为应该推广双壳贝礁, 他们可以作为提供生物多样性和沿海保 护的自然方案, 并可以帮助减缓和适应气候变化。为了成功恢复这些栖息地, 相关人员应该考虑一个总体框架, 在这个框架中, 栖息地要求, 环境背景和较 远栖息地之间相互依赖性应当进行综合考量。
\end{abstract}

Keywords Ecosystem engineers · Oyster reefs $\cdot$ Ecosystem services $\cdot$ Coastal protection $\cdot$ Facilitation of habitats

关键词 生态工程 - 牡蚛礁 - 生态服务 - 海岸线保护 - 栖息地恢复 


\subsection{Bivalves as Ecosystem Engineers}

Ecosystem engineers are organisms that have morphological and/or behavioral traits that enable them to modify, maintain and/or create habitats (Jones et al. 1994). They induce physical state changes in abiotic and biotic materials, thereby regulating the availability of resources to other organisms. This alters the availability of ecological niches to other species, facilitating certain species and inhibiting others (Bruno et al. 2003; Bouma et al. 2009). Jones et al. (1994, 1997) distinguished two types of ecosystem engineers. Autogenic ecosystem engineers change environments through their physical structures (e.g. vegetation, coral reefs), in other words they are part of the engineered habitat, whereas allogenic ecosystem engineers transform living or non-living materials from one physical state to another (e.g. beavers, bioturbating worms).

Bivalves are conspicuous ecosystem engineers that often have both autogenic and allogenic characteristics. In general, in soft-sediment environments, bivalves can be divided into epibenthic and endobenthic organisms depending on whether they spend most of their lifetime above or below the sediment, respectively. Many endobenthic bivalves such as cockles and clams modify the sedimentary habitat through their behavior and can be considered allogenic ecosystem engineers (Bouma et al. 2009). They affect a number of resources mainly through bioturbation and bioirrigation (Reise 2002; Ciutat et al. 2007; Montserrat et al. 2009), but in high densities they also can increase sediment stability (Donadi et al. 2013). The most prominent epibenthic ecosystem engineers inhabiting bare coastal sediments are reef building bivalves. The best-known examples of reef-building bivalves are intertidal and shallow subtidal mussels (Mytilidae) and oysters (Ostreidae). These epibenthic ecosystem engineers modify the sedimentary habitat mainly through their physical structures, and thus are true autogenic ecosystem engineers (Gutiérrez et al. 2003, Bouma et al. 2009). At the same time they are active filter feeders, removing large quantities of suspended material from the water column, influencing water clarity and quality, and producing faecal and pseudofaecal biodeposits that accumulate in the reef and its surroundings (Newell 2004; Kellogg et al. 2013). So, these epibenthic ecosystem engineers have both autogenic and allogenic properties.

Coastal engineers characterise structures such as coral and oyster reefs as low crested or submerged breakwaters and have modelled and validated the effect of these structures on wave height and current velocities (Van der Meer et al. 2005). However, the literature describing the impact of natural reefs on disrupting wave energy is much better developed for coral reefs than bivalve reefs (Sheppard et al. 2005; Rogers et al. 2013; Ferrario et al. 2014). This has included how reef parameters and morphology influence the physics of wave attenuation and flooding (Monismith 2007; Lowe et al. 2010; Quataert et al. 2015).

In this paper, we focus on the ecosystem engineering effects of intertidal and shallow subtidal reef-building bivalves in soft-sediment environments, thereby focusing on the bio-physical interactions these organisms have with their 
environment and two ecosystem services these interactions provide, (1) coastal protection (i.e. erosion control and shoreline stabilization) and (2) habitat for species by facilitation of other marine habitats and species (i.e. increasing biodiversity at large landscape scale). Using two case studies, one in the US and one in the Netherlands, we subsequently show how constructed oyster reefs contribute to shoreline and salt marsh protection or erosion control.

The shift in species composition at the spatial scale of the engineered habitat, this is within the footprint of the reef structure, is discussed in two other papers within this book, namely the effect on associated benthic macroinvertebrates (Craeymeersch and Jansen 2019) and the effect on finfish and crustacean production (Hancock and zu Ermgassen 2019).

\subsection{Characteristics of Epibenthic, Reef-Building Bivalves}

Epibenthic, reef-forming bivalves create spatially and topographically complex habitats and can be found in a wide range of spatial scales, from small clumps to large patches to extensive beds and reefs that cover thousands of square meters and extend kilometres in length (Gutiérrez et al. 2003, 2011) (Fig. 13.1). Bivalves attach
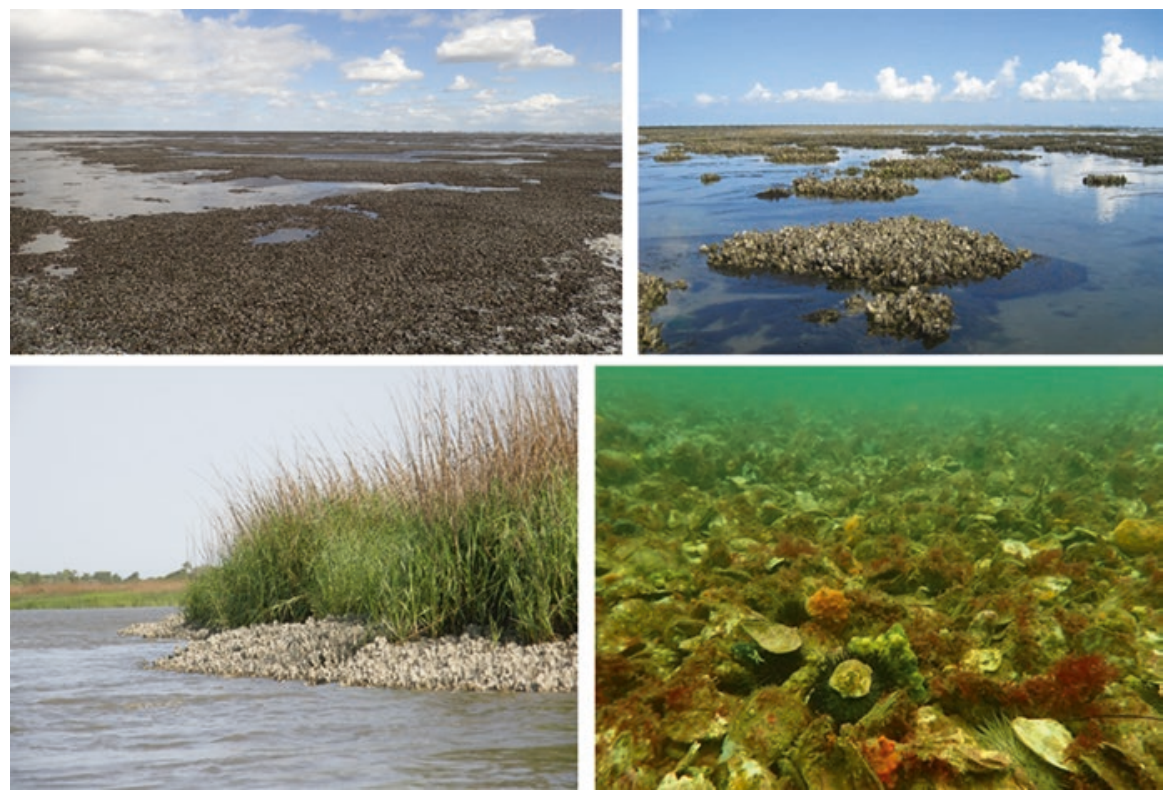

Fig. 13.1 Examples of epibenthic bivalve reefs: (top left) extensive mussel beds (Mytilus edulis) in the Wadden Sea, The Netherlands (K. Troost - WMR, (top right) extensive oyster reefs (Crassostrea gigas) in the Oosterschelde, Netherlands (T. Ysebaert - WMR), (bottom left) Fringing reef, Georgia, USA (M. Spalding - TNC), (bottom right) oyster reef, Georges Bay, Tasmania, Australia (C. Gillies - TNC) 
themselves to the substrate or to each other via byssal threads (e.g. mussels like Mytilus edulis, Musculista senhousia) or via calcification, this is cementing themselves to the substrate or to each other (oysters like Crassostrea gigas, Crassostrea virginica, Ostrea edulis). This makes individual mussels more mobile compared to oysters, on the other hand reefs of mussels will be less persistent compared to oysters, whose structure will persist for a long time, even after dying off of the reef.

The often distinct spatial patterns observed in reef-building bivalves are caused by feedback loops and self-organization processes at different spatial scales and lead to complex habitat forms (Bertness and Grosholz 1985; van de Koppel et al. 2005, 2008). Mussels like the Blue mussel (Mytilus edulis) typically attach themselves to a hard substrate or to each other by forming byssal threads. To find protection or food, mussels can move by releasing the byssal threads and using its foot to move to a new location. Liu et al. (2014) demonstrated that in mussel beds, selforganization generates spatial patterns at two characteristic spatial scales: smallscale, net-shaped patterns due to individual movements (i.e. behavioural aggregation) of individuals, and large-scale, regular banded patterns due to the interplay betweenmussel facilitation and long-distance competition for algae. The interplay between self-organizing processes at individual and ecosystem level is therefore a key determinant of the functioning and resilience of mussel beds (Liu et al. 2014). A decrease of water depth over blue mussel Mytilus edulis mounds results in an increase in water flow, enhancing food transport to the mussels on top of mounds. This locally lowers algal depletion resulting in higher net growth on top of the mounds (positive feedback loop) (Liu et al. 2012).

Oysters typically build reefs through the gregarious settlement of multiple generations onto existing oyster substrate. The shells provide a solid substrate on which new oyster larvae can attach, increasing larval survival by providing shelter from predators and preventing burial in sediment (Mann and Powell 2007). Each generation of larvae settle on top of the preceding generation so that the reef grows vertically and becomes highly complex, with many structural irregularities and infoldings (Dame 2005; Rodriguez et al. 2014). Once settled, oysters are less mobile compared to mussels. But also oyster reefs appear in distinct reef morphologies and spatial patterns, thought to arise from feedback mechanisms between oysters and local hydrodynamics (Lenihan 1999; Dame 2005; Colden et al. 2016). Colden et al. (2016) describe three different reef types or morphologies for the Eastern oyster (Crassostrea virginica) based on historical work by Grave (1905): string reefs, fringe reefs and patch reefs.

\subsection{Interaction with the Local Environment}

Reef-building bivalves add hard substrate to an otherwise soft, more unstable, and often relatively flat bottom in sedimentary environments. By forming complex, three-dimensional structures on top of the sediment surface, epibenthic bivalve 
reefs influence local hydrodynamics and sediment dynamics (Lenihan 1999; Gutiérrez et al. 2003). Epibenthic bivalves enhance near-bed turbulence and vertical mixing in the lower water column and slow down current velocities through increased roughness of the bed (Widdows et al. 2002). Epibenthic bivalve reefs, especially oyster reefs, are often mentioned to act as breakwaters that can attenuate waves (Grabowski and Peterson 2007; Scyphers et al. 2011), but empirical evidence is scarce. Flume studies by Borsje et al. (2011) and Manis et al. (2015) showed that oysters effectively reduce wave energy compared to bare sediment. Lunt et al. (2017) measured in the field wave height and current speed at the windward and leeward side of oyster (Crassostrea virginica) reefs in St Charles and Aransas Bays (Texas, USA), with average wave height (average: leeward $0.05 \mathrm{~m}$, windward $0.22 \mathrm{~m}$ ) and current speed (average: leeward $3.75 \mathrm{~cm} \mathrm{~s}^{-1}$, windward $6.68 \mathrm{~cm} \mathrm{~s}^{-1}$ ) highest on the windward side of oyster reefs.

Epibenthic bivalve reefs exert a strong effect on the benthic-pelagic coupling through their suspension feeding behavior, feeding on seston in the water column and transferring undigested organic and inorganic material in their faeces and pseudofaeces to the sediment surface (Dame 1996; Newell 2004). When abundant, bivalves can exert top-down control on the phytoplankton, thereby reducing turbidity and increasing water transparency (see Cranford 2019).

\subsection{Ecosystem Engineers Offer Essential Ecosystem Services Including Coastal Protection and Habitat for Species}

Coastal ecosystems are increasingly recognized as essential elements in ecosystem restoration and coastal adaptation (Cheong et al. 2013; Temmerman et al. 2013). The capacity of marshes and shellfish reefs to maintain their own habitat via biophysical feedbacks, and their ability to grow with sea-level rise is seen as an important advantage over traditional man-made hard engineering structures (Rodriguez et al. 2014; Kirwan et al. 2016; Walles et al. 2015b). Ecosystem engineers, in particular, are increasingly recognized for their role in delivering important ecosystem services that serve human wellbeing. In case of epibenthic bivalve reefs, ecosystem services include a myriad of provisioning, regulating, habitat and cultural services (Coen and Luckenbach 2000, Coen et al. 2007, Beck et al. 2009, Grabowski et al. 2012, and papers within this book). Here we focus on two services, namely the regulating service coastal protection (coastal erosion prevention, shoreline stabilization) and the supporting/habitat service habitat for species (enhancement of biodiversity and diversification of the landscape). The latter specifically deals with the extending effects outside the boundary of the reef structure itself. Figure 13.2 visualizes these ecosystem services in a cross-section along a shoreline.

In their natural setting, bivalve reefs attenuate wave energy and stabilize sediments, protecting adjacent habitats such as intertidal flats, sea grasses and salt 


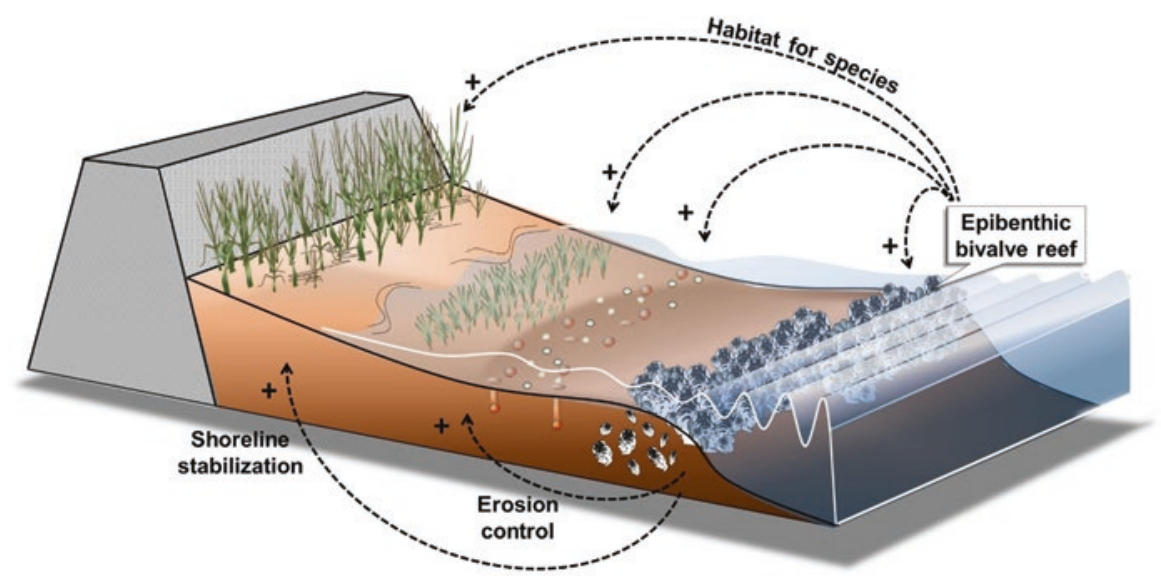

Fig. 13.2 Visualisation of the ecosystem services delivered by epibenthic bivalve reefs. Reefs provide coastal protection through erosion control and shoreline stabilization, and modify the physical landscape by ecosystem engineering, thereby providing habitat for species by facilitative interactions with other habitats such as tidal flat benthic communities, sea grasses and marshes

marshes against erosion. As coastal erosion is an increasing problem worldwide, due to human interventions, worsened by climate induced sea level rise and more frequent storms, shellfish reefs are therefore an attractive living shoreline approach that can be used for shoreline protection and erosion control along eroding coastlines, offering an alternative to artificial shoreline hardening (Meyer et al. 1997; Piazza et al. 2005; Scyphers et al. 2011; La Peyre et al. 2015; Walles et al. 2016a) (Fig. 13.3). For example, 30\% of the oyster restoration projects in the US involve coastal protection as one of the targets (http://projects.tnc.org/coastal/). Besides relatively small restoration projects, increasingly large projects are in development. In Alabama there is a long range goal to construct 100 miles of oyster reef for shoreline protection and conservation of coastal marshes and seagrasses. This work has developed into large shoreline protection projects using oyster reef in all the US Gulf of Mexico states, valued at over \$178 Million US (See case study 1). In the Netherlands, $1.3 \mathrm{~km}$ of oyster reefs were constructed in the Eastern Scheldt for erosion control of intertidal flats (Walles et al. 2016a, see case study 2).

Another important ecosystem service delivered by bivalve reefs is the provision of habitat(s) for species, leading to enhancement of biodiversity and diversification of the landscape. Indeed, the spatial impact of the ecosystem engineering effects of reefs is much larger than the size of the reef footprint. By influencing hydrodynamics oysters and mussels modify the sedimentary environment and physical landscape far beyond the boundaries of the reef, affecting morphological and ecological processes up to several hundreds of meters. Biodeposition of organic material in the form of faeces and pseudofaeces changes the sediment composition and enhance primary production of microphytobenthos in the surroundings (Newell 2004; Donadi et al. 2013; Engel et al. 2017). Walles et al. (2015a) demonstrated alteration of tidal flat morphology by Pacific oyster Crassostrea gigas reefs up to tens or 

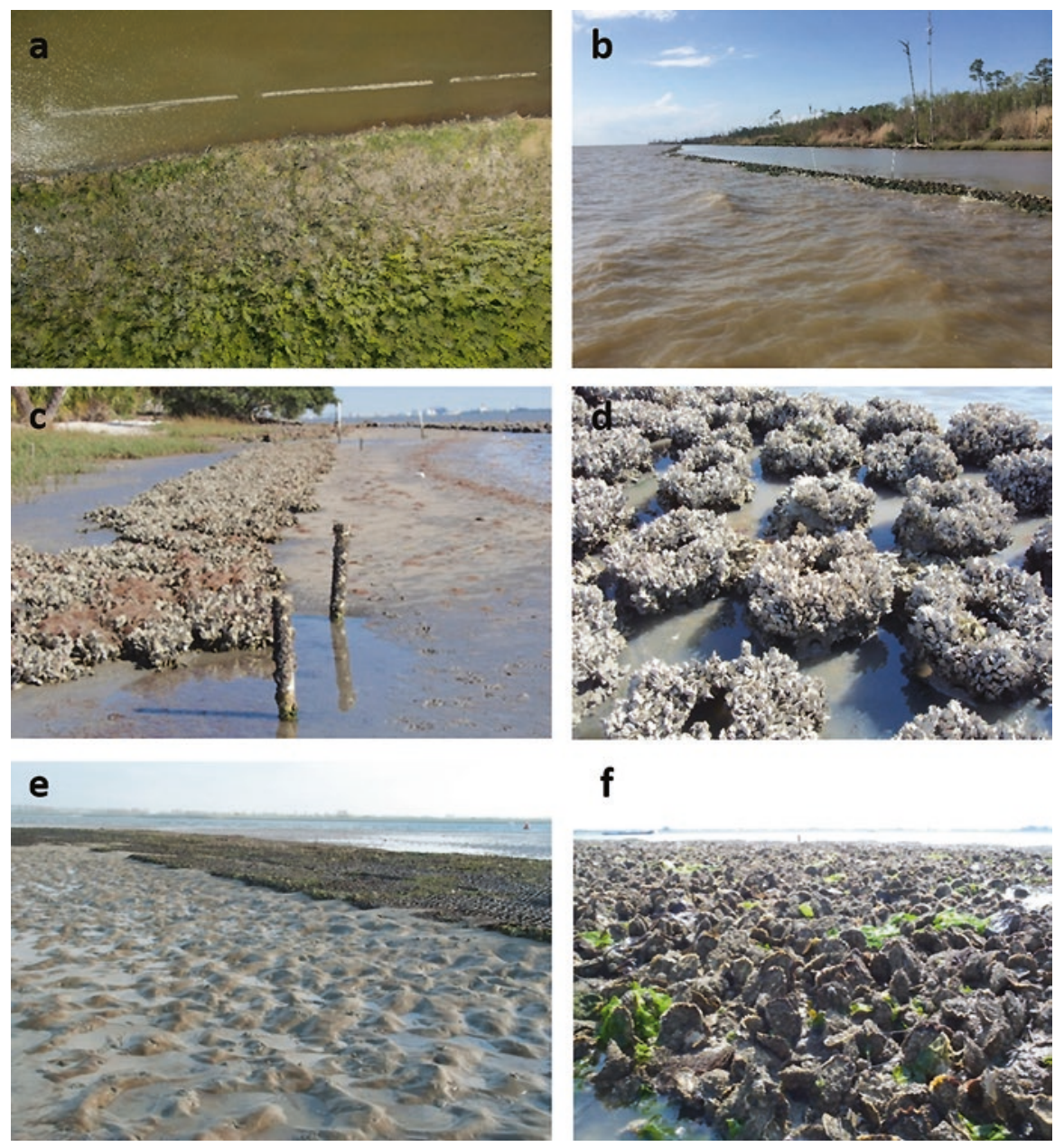

Fig. 13.3 Examples of reefs constructed for shoreline protection and erosion control. (a) Reefs constructed for shoreline protection at Swift Tract Alabama, USA (M-K Brown, TNC); (b) Swift Tract reef demonstrating wave attenuation (M-B Charles, TNC); (c) Reef grown on concrete domes for shoreline protection, Tampa Bay, Florida, USA (B. Hancock, TNC); (d) Concrete domes with 3 years of oyster growth, Tampa Bay, FL, USA (B. Hancock, TNC); (e) Reef consisting of gabions filled with oyster shells constructed for erosion control of an intertidal mudflat of Viane, Oosterschelde, The Netherlands (T. Ysebaert, WMR); (f) Reef at Viane after 3 years of oyster growth, Oosterschelde, The Netherlands (B. Walles, WMR)

hundreds of meters in the Oosterschelde estuary (The Netherlands). Nieuwhof et al. (2017) demonstrated increased water storage capacity on intertidal flats as a consequence of the enhanced engineering by shellfish reefs. In the Wadden Sea zonation of biological communities was observed as a consequence of the long-distance, cross-habitat interactions with mixed blue mussel Mytilus edulis and Pacific oyster Crassostrea gigas reefs (van de Koppel et al. 2015). These interactions were shown 
to be scale-dependent: at short distances cockle (Cerastoderma edule) abundance was suppressed, whereas at larger distances increased spatfall and better survival of adult cockles was observed due to reduced sediment erosion (Donadi et al. 2013). This in turn influenced higher trophic levels, such as shorebirds that feed upon cockles (Donadi et al. 2013, van der Zee et al. 2012). Other studies showed cross-habitat interactions between epibenthic, suspension feeding bivalves and seagrass habitats (Peterson and Heck 2001; Newell and Koch 2004) and marshes (Meyer et al. 1997; Piazza et al. 2005). Therefore, at the landscape level, ecosystem engineering typically enhances environmental heterogeneity, thereby increasing niche opportunities and eventually the diversity of communities and habitats such as sea grasses, marshes and mangroves (van de Koppel et al. 2015). The facilitation of these vegetated habitats in turn also deliver essential ecosystem services (Barbier et al. 2011) and coastal plant communities are increasingly recognized for their capacity for climate change adaptation and mitigation (Duarte et al. 2013). Marshes and mangroves overall have higher potential as natural defences for coastal protection, but restoration of bivalve reefs in front of these vegetated habitats can strengthen their growth and survival. Therefore, epibenthic bivalve reefs are as such not suitable for use as primary flood defences, due to their relatively low position in the intertidal zone, but indirectly, through their long-distance effects and facilitative interactions on other habitats, will add to the protection and flood defence of our coasts and improve the resilience of ecosystem-based coastal defence practices (Temmerman et al. 2013).

\subsection{Study Case 1: Oyster Reefs for Shoreline and Salt Marsh Protection in Coastal Alabama, USA}

In the northern Gulf of Mexico (USA), several coastal habitats have suffered declines of more than $50 \%$ over the last century, including seagrass, wetlands, and oyster reefs. Locally, Alabama has lost some $70 \%$ of its seagrass habitat, $85 \%$ of its oyster habitat, and thousands of acres of wetlands. Loss of nearshore habitats has been caused by decreased water quality, dredge-and-fill activities, construction of seawalls, jetties and groins among other causes, but in the case of oyster habitat mainly from overfishing (Beck et al. 2011). Increased erosion is due to increased ship wakes from the channel to the Alabama Port in Mobile as well as seasonal storms, sea level rise and climate change, and has been exacerbated by the loss of habitat such as oyster reef that can reduce wave energy before it reaches the coast. The declines, along with increasing appreciation of the value of the services these habitats provide, have prompted increased efforts to restore these habitats and ecosystem services. A goal of many habitat restoration projects has been shoreline protection (e.g. living shorelines, constructing oyster reef to act as breakwaters and beneficial use of dredge material) (Kroeger and Guannel 2014). Coastal Alabama hosts some advanced and well documented ecological studies that demonstrate the 
potential for restoring degraded habitats and enhancing many ecosystem services for community resilience, wave attenuation, shoreline protection, and fish production (Coen and Luckenbach 2000; Piazza et al. 2005; Grabowski and Peterson 2007; Gregalis et al. 2009; Powers et al. 2009; Scyphers et al. 2011; Grabowski et al. 2012; La Peyre et al. 2014; Scyphers et al. 2015; zu Ermgassen et al. 2016).

In 2009 the Obama administration provided funds for economic stimulus to counter the recession triggered by the real estate collapse in 2008 (https://www. treasury.gov/initiatives/recovery/Pages/recovery-act.aspx). Some of these funds were directed toward habitat restoration and used to move what had generally been 'proof of concept' scale work to an ecosystem scale. In Mobile Bay, AL, a coalition of partners led by The Nature Conservancy used this opportunity to implement large scale oyster habitat restoration directed primarily toward shoreline protection (Kroeger and Guannel 2014). This approach has been continued through the successful engagement of municipalities and communities across the Alabama coast, the development and implementation of watershed management plans (WMP) and additional shoreline protection projects. Socioeconomic studies of coastal Alabama residents have demonstrated an awareness of the decline of coastal habitats, a broad appreciation that they provide important ecosystem services, and substantial support for enhancing coastal resilience (Scyphers et al. 2014a, 2014b).

A substantial investment ( $\$ 50$ M US dollar) has been made in more than 13 completed and 5 progressing restoration projects in coastal Alabama to the end of 2017 (Table 13.1). Data from 13 projects completed by multiple partners is currently being synthesised to determine which techniques have worked best for oyster recruitment, fisheries production and shoreline protection, including an economic valuation of the outcomes. At the time of writing, project monitoring has highlighted a need for some specific enhancements on the initial habitat restoration projects to improve functionality, as well as to add additional benefits beyond the original objectives. For these existing restoration projects, adaptive management strategies informed by long-term monitoring will be implemented to enhance these current investments and further improve future projects.

For example, in early 2011 following the Deepwater Horizon oil spill, at a site known as Helen Wood Park, 12 intertidal reefs were constructed to protect the

Table 13.1 Total RESTORE Act Investments in Oyster Reefs by State for the US Gulf of Mexico

\begin{tabular}{l|l|l|c|c}
\hline State & Number of projects & Total $\$ \$($ approved/allocated/spent) & Total miles & Total acres \\
\hline Florida & 5 & $\$ 17,330,718$ & 9.95 & 4 \\
\hline Alabama & 9 & $\$ 53,829,415$ & 10.13 & 0 \\
\hline Mississippi & 4 & $\$ 85,820,460$ & 18.8 & 100 \\
\hline Louisiana & & & & \\
\hline Texas & 10 & $\$ 16,183,000$ & 8.21 & 50 \\
\hline TOTAL & 28 & $\$ 178,163,593$ & 47.09 & 154
\end{tabular}

https://www.restorethegulf.gov/sites/default/files/FPL_forDec9Vote_Errata_04-07-2016.pdf; http://www.nfwf.org/gulf/pages/gulf-projects.aspx; http://www.alabamacoastalrestoration.org/ NRDA/Prior-Announcements (Phase I, III and IV))

aLouisiana has substantial investment but data are not readily available 


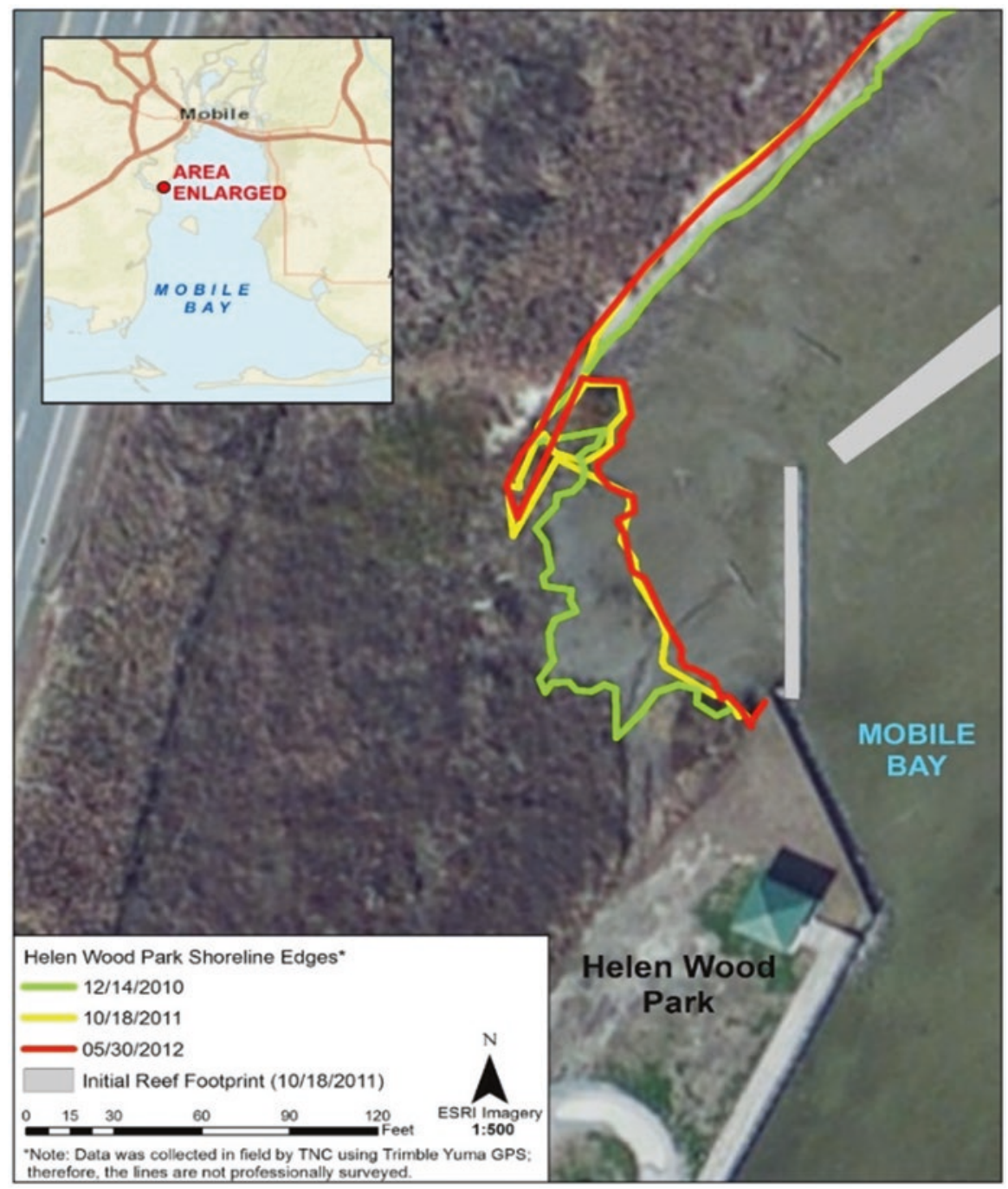

Fig. 13.4 Shoreline change at Helen Wood Park's south marsh December 2010, October 2011 and May 2012. The constructed oyster reefs are shown as grey rectangles

$392 \mathrm{~m}$ shoreline and provide habitat. The site has been impacted by adjacent development (seawall) and has experienced significant erosion. The reefs measured $\sim 25 \mathrm{~m}$ long and 2-3 m wide with $7.5 \mathrm{~m}$ gaps. A combination of natural and engineered materials was used, with 4 reefs constructed using concrete Reefballs, 7 reefs were constructed using bagged oyster shell, and 1 reef being partly made of Reefballs and partly bagged oyster shells. Shoreline position, reef footprints and recruitment of sessile organisms was monitored annually. Approximately one year post-construction, the marsh at the south end had expanded by some 7\% and accumulation of sediment leeward of the structures had occurred (Fig. 13.4). 


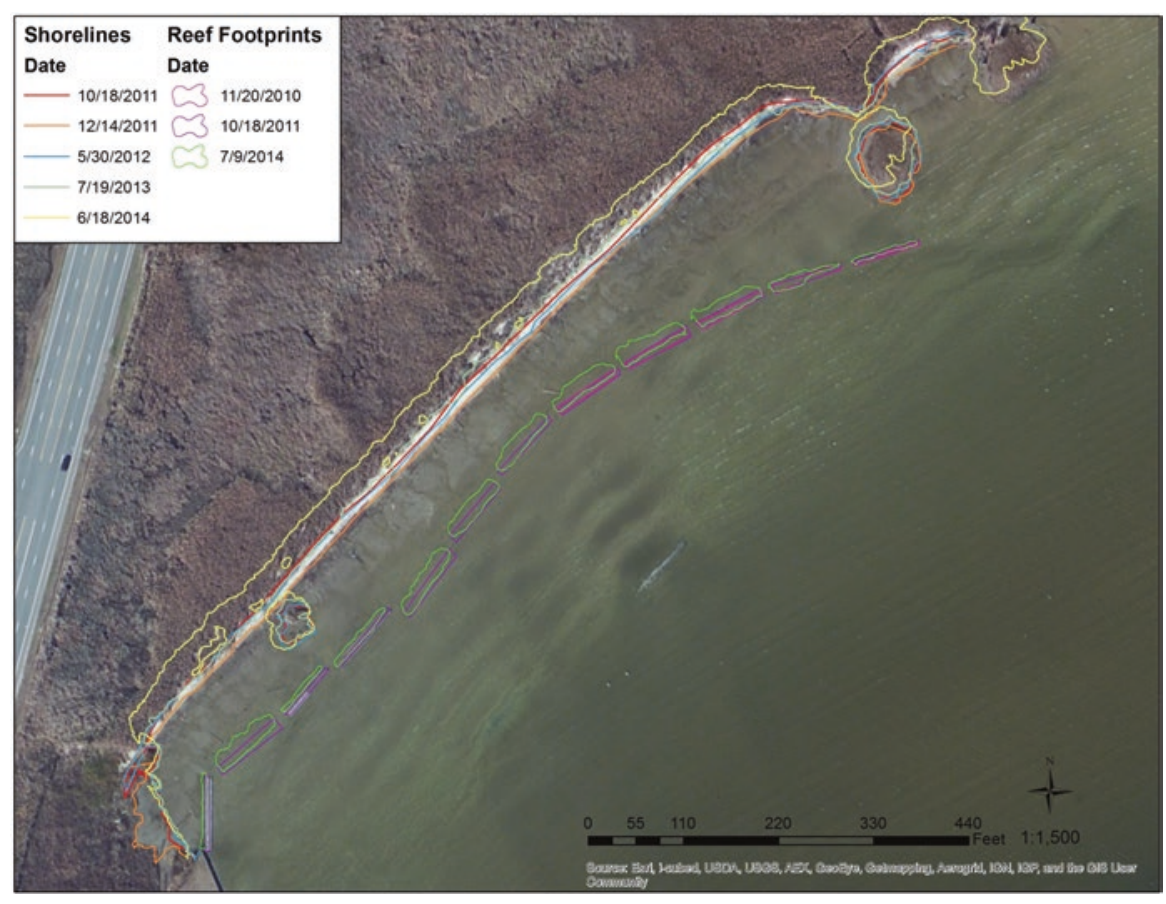

Fig. 13.5 Reef footprints at Helen Wood Park with purple lines showing as built outline in spring 2011. The green line (2014) shows changes after 3 years. The reefs measured $\sim 25 \mathrm{~m}$ long and 2-3 m wide with $7.5 \mathrm{~m}$ gaps. The two reefs on the left are bagged oyster shells and the reef on the right made of Reefballs. The second reef on the right is partly made of Reefballs (right side) and partly bagged oyster shells (left side)

As monitoring continued, by year 3, the bagged shell reefs had noticeably broken down. Their footprint expanded as the shell spread, and the vertical structure had decreased (Fig. 13.5). While the use of bagged oyster shell was preferred for conspecific recruitment, as well as aesthetics, this substrate broke down after 3-4 years, providing reduced wave attenuation and shoreline protection (Unpublished data).

The long-term monitoring conducted at the Helen Wood Park site was used to inform subsequent projects to increase project success and longevity. For example, the $940 \mathrm{~m}$ Swift Tract project was completed in the summer of 2012. The construction technique utilized at the Swift Tract consisted of Hesco barriers, galvanized steel modular baskets that were installed and then filled with gabion stone. A $0.15 \mathrm{~m}$ layer of oyster shell was placed on top of the gabion stone within the cages. Pockets on the front and rear sides of the Hesco barriers $\sim 0.15 \mathrm{~m}$ deep were filled with oyster shell. Five individual segments were constructed, each $\sim 125 \mathrm{~m}$ long and $5.5 \mathrm{~m}$ wide, with $12 \mathrm{~m}$ gaps between. This hybrid technique used cages and rock to retain vertical structure and oyster shell for oyster and mussel settlement.

This shoreline at Swift Tract had been experiencing erosion, so one of the project objectives was to reduce wave energy impacting the shore. Historically (1957- 


\section{Swift Tract Annual Shoreline Movement Rates Pre- and Post-Construction}

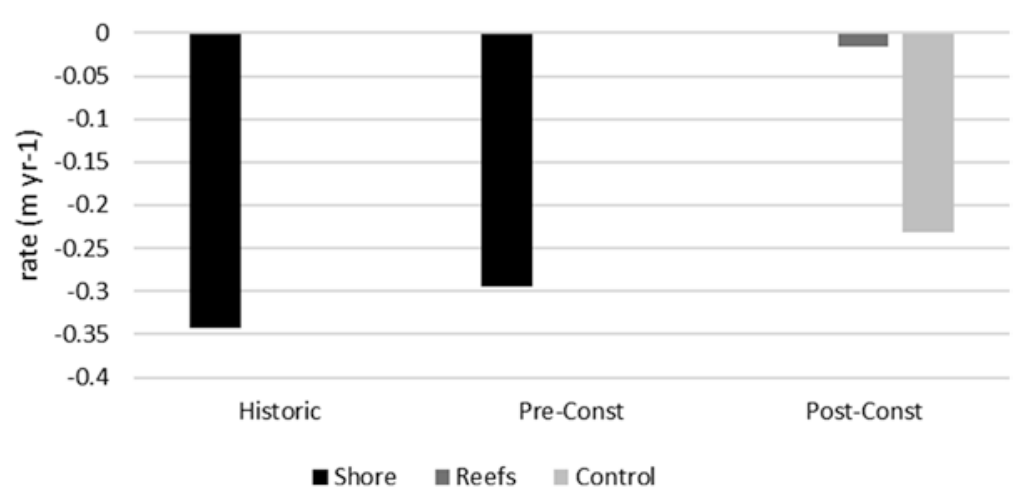

Fig. 13.6 Annual rate of shoreline loss at Swift Tract during two time periods prior to construction of reef structures, with the reduced rate of post-construction shoreline loss associated with the reefs compared to adjacent control sites

1981), just under $0.35 \mathrm{~m}$ of shoreline was lost each year. In the time immediately prior to reef construction (1981-2011), the rate of loss was approximately $0.3 \mathrm{~m} / \mathrm{yr}$. With 4 years of data following reef construction, the annual shoreline loss has dropped to $\sim 0.02 \mathrm{~m} / \mathrm{yr}$. (Fig. 13.6). The materials used have not lost their vertical structure during the first 5 years of monitoring. It is possible that given a longer monitoring period ( $>4$ years) we may find that the shoreline has stabilized.

While progress has been made toward reducing shoreline erosion in Alabama, a coordinated and comprehensive effort to restore shorelines is necessary to help maximize these benefits for both the communities and the natural habitats. Like traditional bulkheads, nature-based or hybrid shoreline restoration options are not one-size-fits-all. By developing a ready-to-implement plan for a range of individual sites, communities and residents will have a resource available to guide restoration activities that help make their communities more resilient, while also improving habitat and water quality. Broader implementation of sound restoration techniques at the place-based level can:

- improve coastal and community resilience by incorporating multiple individual efforts to maintain and improve municipal Community Rating System (CRS) rankings for coastal insurance incentives,

- enhance coastal habitat, such as marsh, to uptake nonpoint source nutrients and pathogens and improve water quality before runoff enters coastal tributaries,

- improve estuarine habitat for fish and shellfish, coastal birds and other wildlife.

These projects, with the benefit of the lessons learned and adaptive management, can provide long term benefits for the broader community by enhancing fisheries, providing recreational opportunities, improving water quality, retaining property 
and land values, and increasing community resilience. Collectively, these benefits contribute to a stronger economy and better quality of life.

\subsection{Study Case 2: Oyster Reefs as Protection Against Tidal Flat Erosion, Oosterschelde, The Netherlands}

In the Netherlands three intertidal oyster reefs were constructed in 2010 in the Oosterschelde to investigate their contribution to coastal protection, acting as a natural buffer for erosion control. The Oosterschelde is a coastal bay (tidal range at the study site $3 \mathrm{~m}$, salinity $30 \mathrm{ppt}$ ) that suffers from eroding intertidal flats, due to infrastructural works (i.e. construction of a storm-surge barrier) in the 1980s (Nienhuis and Smaal 1994; Walles et al. 2016a). Tidal flats are eroding on average $1 \mathrm{~cm} . \mathrm{yr}^{-1}$ in height, and it is predicted that more than half of the 11,000 hectares will be lost by the end of this century. This has consequences for both nature values as well as coastal protection, as the tidal flats are foraging grounds for an internationally important number of waders like Oystercatchers (Haematopus ostralegus), and at the same time protect the dikes against wave erosion.

The constructed reefs, made of $25 \mathrm{~cm}$ high gabions filled with Pacific oyster shells, provided substrate for settlement of new oyster recruits. To attenuate waves, the $200 \mathrm{~m}$ long reefs were positioned perpendicular to the dominant wave direction at three different elevations: 23\%, 35\% and 50\% emersion time (Walles et al. 2016a) (Fig. 13.3). Over a 5-year period, the development of these reefs and their effect on tidal flat morphology (erosion/sedimentation) were monitored.

Reef development was related to vertical position in the intertidal zone. Recruitment rate, shell growth, and the condition of the oysters (Crassostrea gigas) were correlated with tidal emersion (Walles et al. 2016b). The reef positioned at $50 \%$ tidal emersion lacked sufficient settlement of new oyster recruits to maintain the reef structure. As such, the constructed reef shows a continuous deterioration. The reefs positioned at $35 \%$ and $23 \%$ tidal emersion had sufficient recruitment to maintain their structures. Oyster grew at both reefs, however a loss in weight and a low condition of the oysters on the reef at $35 \%$ tidal emersion indicated stress at this elevation (Fig. 13.7). Rodriguez et al. 2014 showed that reefs have an upper limit with respect to tidal range, a so-called growth ceiling above which reefs cannot grow as stress from limited inundation is too high. For natural reefs in the Oosterschelde the growth ceiling occurs above $60 \%$ tidal emersion (Walles et al. $2016 \mathrm{~b}$ ). Based on growth rates observed on the lowest reef, a vertical accretion of the reef base in the order of 7.0-16.9 $\mathrm{mm} \mathrm{year}^{-1}$ is expected (Walles et al. 2016a). This is an underestimation of the real reef growth as vertical accretion of the taphonomically active zone is much higher. Over the course of 5 years this reef increased on average $10 \mathrm{~cm}$ (unpublished data).

Measurements of waves windward and leeward of the reefs showed that wave attenuation is depending on the size of the incoming waves and the water depth over 


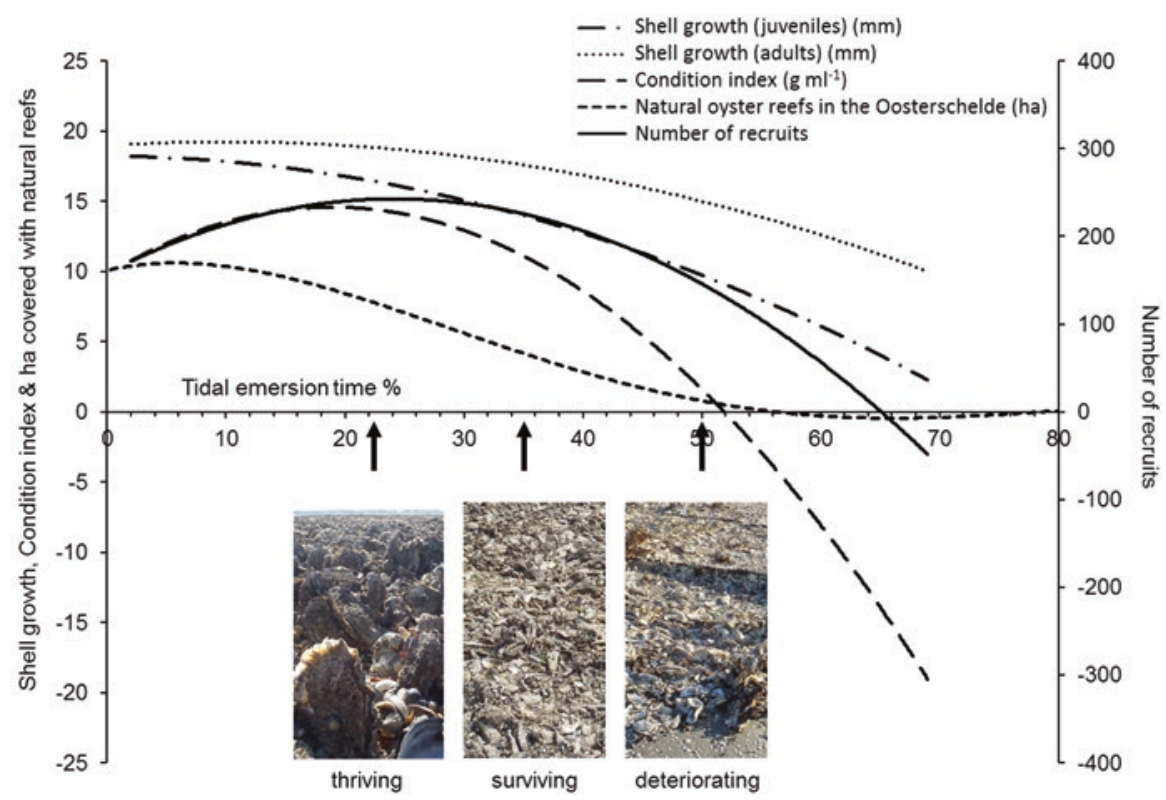

Fig. 13.7 The occurrence of Pacific Oyster reefs and the response curves of recruitment, shell growth condition index of oysters, and reef area, along a tidal emersion gradient in the Oosterschelde (adapted from Walles et al. 2016b). Pictures of the reefs positioned along the tidal emersion gradient show the different development stages of the reefs, with a thriving population at $23 \%$ tidal emersion and a deteriorating reef at $50 \%$ tidal emersion

the reef structure. Close to submergence, reefs potentially attenuate waves up to 95\% of the incoming waves. For larger water depths, the attenuation depends on the wave height and wave length. We found that wave height leeward of the reef relates to water depth on top of the reef with a factor of 0.3. This is comparable to rubble mount breakwaters (Van der Meer et al. 2005). For example, for a water depth of $1 \mathrm{~m}$ on top of the reefs, waves smaller than $30 \mathrm{~cm}$ will not be influenced by the reef anymore.

Elevation measurements showed that the reef positioned at 23\% tidal emersion, effectively reduced erosion leeward of the reef, as predicted (Walles et al. 2015a). Up to $90 \mathrm{~m}$ leeward of the reef there was a reduction of $51 \pm 29 \%$ in the erosion measured. The reef however influences the morphology over a much larger area, up to $360 \mathrm{~m}$ leeward of the reef. 


\subsection{Management Applications and Considerations}

There is growing interest in the restoration and conservation of epibenthic bivalve reefs for coastal protection and shoreline stabilization, also because of their potential to adapt to climate change impacts and sea level rise. This is evidenced by the growing number of projects and studies done worldwide, as well as the increasing funding for nature-based defences or living shoreline initiatives. Despite increasing interest in restoration, the success of bivalve reef restoration is variable (Coen et al. 2007; Mann and Powell 2007). Yet, there are few syntheses of information on what kind of projects meet the goals or are cost effective (Grabowski et al. 2012; Bayraktarov et al. 2016). Data from monitoring the success or failure of restoration projects are not always consistent or readily available, or projects lack sound monitoring efforts at all (Baggett et al. 2015). In order to properly develop guidelines and methodologies for project design, monitoring whether a restoration project designed for coastal protection (or another ecosystem service) has achieved its stated objectives is necessary and should be incorporated in each project setup. A general framework that considers both project success and cost-benefits of restoring epibenthic bivalve reefs for coastal protection or facilitation of other habitats is needed for each project. Therefore, it is necessary to consider carefully how to design and implement restoration projects given the stated goals and targeted ecosystem services. Understanding the interaction between reef-forming ecosystem engineers and the surrounding environment is of utmost importance and several aspects need to be considered when restoring or creating epibenthic bivalve reefs for coastal protection or facilitation of other habitats. First, using epibenthic bivalve reefs for coastal protection or facilitation of other habitats requires knowledge about the habitat requirements of the targeted bivalve species, or 'site suitability' for the selected species (La Peyre et al. 2015). Recruitment, growth and survival of epibenthic bivalves depend on many factors, including salinity, temperature, dissolved oxygen, hydrodynamics, tidal emersion and wave exposure (Baggett et al. 2015; Walles et al. 2016c; Theuerkauf et al. 2017). In addition, biological factors, such as availability of larvae, predation pressure and diseases will influence the long-term survival and sustainability of the constructed reef. This all determines whether a certain site is suitable for the construction of a bivalve reef.

Second, to get optimal effect on shoreline stabilization or facilitation of other habitats, reefs should be constructed at the right position in the intertidal or shallowsubtidal zone. Wave dampening by shellfish reefs depends on water depth (tidal range), wave height/length, and reef height/width. The latter implies that design parameters are also crucial aspects for successful restoration for shoreline protection. Based on the slope of the area the long-term distance of influence by the reef can be estimated. One should realise that there are limitations on the extent that oyster reefs offer shoreline protection or erosion control. When positioned properly, and with the right conditions, reefs can dampen waves considerably, interacting over long distances with the seabed, reducing erosion and facilitating neighbouring habitats and ecosystems such as tidal flats, seagrasses and salt marshes. In other 
cases, for instance when the bed slope is very steep or the tidal range large, the effect will be strongly reduced. Additionally, the role of reefs in stabilizing the substrate underneath their footprint is a currently under-appreciated service that helps in armouring the coast against erosion.

Thirdly, when one knows where a bivalve reef can potentially grow and act as coastal defence or habitat facilitator, the restoration itself also requires attention. Restoration of epibenthic bivalve reefs can be done in several ways. For oysters, typically some kind of substrate is offered on which oyster larvae can settle. Oyster larvae preferentially settle on conspecifics, so adding loose oyster shells is often used in low-dynamic, sheltered environments, whereas shells packed in bushels or gabions are needed in more dynamic situations. Often there is a shortage of oyster shells, and other substrates are being used such as reef balls, oyster castles, etc. (zu Ermgassen et al. 2016). For restoration of mussel beds, it has been proven that taking into account the behavioural self-organisation of mussels improved restoration success considerably (De Paoli et al. 2017).

\subsection{Conclusions}

In conclusion, epibenthic bivalve reefs are conspicuous ecosystem engineers that modify the soft-sediment environment in which they live to a great extent. Both their physical structure and suspension feeding activity strongly influence the neighbouring sedimentary environment up to $100 \mathrm{~s}$ of meters outside their own footprint. Wave attenuation by the reefs reduces erosion, facilitating other species and protecting habitats such as seagrasses and salt marshes. These ecosystem engineering effects of epibenthic bivalve reefs are increasingly recognized and bivalve reefs are promoted as nature-based solutions that provide biodiversity benefits, support many ecosystem services including coastal protection, and contribute to climate change mitigation and adaptation. Much has been learned about how bivalve reefs function and deliver these services, which has accelerated growth and interest in bivalve reef restoration projects ((zu Ermgassen et al. 2016). Objectives for restoration of these reefs should be framed on the basis of the desired ecosystem services provision. This requires a general framework in which habitat requirements of the considered species, environmental setting and long-distance interdependence between habitats are mutually considered (zu Ermgassen et al. 2016).

The coast cannot be restored to its historic condition, but innovation and coordination of techniques and projects can enhance ecosystem function and quality of life and make coastal communities more resilient in the decades to come.

Acknowledgements This work was supported by the Netherlands Organisation for Scientific Research (NWO) via the project "EMERGO - Ecomorphological functioning and management of tidal flats" (850.13.020). The authors are grateful to dr M. Baptist and Dr. B Borsje for reviewing this paper. 


\section{References}

Baggett LP, Powers SP, Brumbaugh RD, Coen LD, Deangelis BM, Greene JK, Hancock BT, Morlock SM, Allen BL, Breitburg DL, Bushek D (2015) Guidelines for evaluating performance of oyster habitat restoration. Restor Ecol 23:737-745

Barbier EB, Hacker SD, Kennedy C, Koch EW, Stier AC, Silliman BR (2011) The value of estuarine and coastal ecosystem services. Ecol Monogr 81:169-193

Bayraktarov E, Saunders MI, Abdullah S, Mills M, Beher J, Possingham HP, Mumby PJ, Lovelock CE (2016) The cost and feasibility of marine coastal restoration. Ecol Appl 26:1055-1074. https://doi.org/10.1890/15-1077

Beck MW, Brumbaugh RD, Airoldi L, Carranza A, Coen LD, Crawford C, Defeo O, Edgar GJ, Hancock B, Kay MC, Lenihan HS, Luckenback MW, Toropova CL, Zhang G (2009) Shellfish reefs at risk: a global analysis of problems and solutions. The Nature Conservancy, Arlington

Beck MW, Brumbaugh RD, Airoldi L, Carranza A, Coen LD, Crawford C, Defeo O, Edgar GJ, Hancock B, Kay MC, Lenihan HS, Luckenbach MW, Toropova WL, Zhang G, Guo X (2011) Oyster reefs at risk and recommendations for conservation, restoration, and management. Bioscience 61:107-116

Bertness MD, Grosholz E (1985) Population dynamics of the ribbed mussel, Geukensia demissa: the costs and benefits of an aggregated distribution. Oecologia 67:192-204

Borsje BW, van Wesenbeeck BK, Dekker F, Paalvast P, Bouma TJ, van Katwijk MM, de Vries MB (2011) How ecological engineering can serve in coastal protection. Ecol Eng 37:113-122

Bouma TJ, Olenin S, Reise K, Ysebaert T (2009) Ecosystem engineering and biodiversity in coastal sediments: posing hypotheses. Helgol Mar Res 63:95-106

Bruno JF, Stachowicz JJ, Bertness MD (2003) Inclusion of facilitation into ecological theory. Trends Ecol Evol 18:119-125

Cheong S-M, Silliman B, Wong PP, van Wesenbeeck B, Kim C-K, Guannel G (2013) Coastal adaptation with ecological engineering. Nat Clim Chang 3:787-791

Ciutat A, Widdows J, Pope ND (2007) Effect of Cerastoderma edule density on near-bed hydrodynamics and stability of cohesive muddy sediments. J Exp Mar Biol Ecol 346:114-126

Coen LD, Luckenbach MW (2000) Developing success criteria and goals for evaluating oyster reef restoration: ecological function or resource exploitation? Ecol Eng 15:323-343

Coen LD, Brumbaugh RD, Bushek D, Grizzle R, Luckenbach MW, Posey MH, Powers SP, Tolley SG (2007) Ecosystem services related to oyster restoration. Mar Ecol-Prog Ser 341:303-307

Colden AM, Fall KA, Cartwright GM, Friedrichs CT (2016) Sediment suspension and deposition across restored oyster reefs of varying orientation to flow: implications for restoration. Estuar Coasts 39:1435-1448

Craeymeersch J, Jansen H (2019) Bivalve shellfish assemblages as hotspots for biodiversity. In: Smaal et al (eds) Goods and services of marine bivalves. Springer, Cham, pp 275-294

Cranford P (2019) Magnitude and extent of water clarification services provided by bivalve suspension feeding. In: Smaal et al (eds) Goods and services of marine bivalves. Springer, Cham, pp 119-141

Dame RF (1996) Ecology of marine bivalves: an ecosystem approach. CRC Press, Boca Raton $254 \mathrm{pp}$

Dame RF (2005) Oyster reefs as complex ecological systems. In: Dame RF, Olenin S (eds) The comparative roles of suspension-feeders in ecosystems, NATO science series IV: earth and environmental series, vol 47. Springer, Dordrecht

De Paoli H, Van der Heide T, Van den Berg A, Silliman BR, Herman PMJ, Van de Koppel J (2017) Behavioral self-organization underlies the resilience of a coastal ecosystem. Proc Natl Acad Sci U S A. https://doi.org/10.1073/pnas.1619203114

Donadi S, van der Heide T, van der Zee EM, Eklöf JS, de Koppel JV, Weerman EJ, Piersma T, Olff H, Eriksson BK (2013) Cross-habitat interactions among bivalve species control community structure on intertidal flats. Ecology 94:489-498 
Duarte CM, Losada IJ, Hendriks IE, Mazarrasa I, Marba N (2013) The role of coastal plant communities for climate change mitigation and adaptation. Nat Clim Chang 3:961-968

Engel FG et al (2017) Mussel beds are biological power stations on intertidal flats. Estuar Coast Shelf Sci 191:21-27

Ferrario F, Beck MW, Storlazzi CD, Micheli F, Shepard CC, Airoldi L (2014) The effectiveness of coral reefs for coastal hazard risk reduction and adaptation. Nat Commun 5:3794. https://doi. org/10.1038/ncomms4794

Grabowski JH, Peterson CH (2007) Restoring oyster reefs to recover ecosystem services. In: Cuddington K, Byers JE, Wilson WG, Hastings A (eds) Theoretical ecology series. Academic, Burlington, pp 281-298

Grabowski JH, Brumbaugh RD, Conrad RF, Keeler AG, Opaluch JJ, Peterson CH, Piehler MF, Powers SP, Smyth AR (2012) Economic valuation of ecosystem services provided by oyster reefs. Bioscience 62:900-909

Grave C (1905) Investigation for the promotion of the oyster industry of North Carolina. In: U.S. fish commission report for 1903, U.S. Commission for Fish and Fisheries, pp 247-341

Gregalis KC, Johnson MW, Powers SP (2009) Restored oyster reef location and design affect responses of resident and transient Fish, Crab, and Shellfish species in Mobile Bay, Alabama. Trans Am Fish Soc 138(2):314-327. https://doi.org/10.1577/T08-041.1

Gutiérrez JL, Jones CG, Strayer DL, Iribarne OO (2003) Mollusks as ecosystem engineers: the role of Shell production in aquatic habitats. Oikos 101:79-90

Gutiérrez JL, Jones CG, Byers JE, Arkema KK, Berkenbusch K, Committo JA, Duarte CM, Hacker SD, Hendriks IE, Hogarth PJ, Lambrinos JG, Palomo MG, Wild C (2011) Physical ecosystem engineers and the functioning of estuaries and coasts. In: Wolanski E, McLusky D (eds) Treatise on estuarine and coastal science. Elsevier, Amsterdam, pp 53-81

Hancock B, zu Ermgassen P (2019) Enhanced production of finfish and large crustaceans by bivalve reefs. In: Smaal et al (eds) Goods and services of marine bivalves. Springer, Cham, pp 295-312

Jones CG, Lawton JH, Shachak M (1994) Organisms as ecosystem engineers. Oikos 69:373-386

Jones CG, Lawton JH, Shachak M (1997) Positive and negative effects of organisms as physical ecosystem engineers. Ecology 78:1946-1957

Kellogg ML, Cornwell JC, Owens MS, Paynter KT (2013) Denitrification and nutrient assimilation on a restored oyster reef. Mar Ecol Prog Ser 480:1-19. https://doi.org/10.3354/meps10331

Kirwan ML, Temmerman S, Skeehan EE, Guntenspergen GR, Fagherazzi S (2016) Overestimation of marsh vulnerability to sea level rise. Nat Clim Chang 6:253-260

Kroeger T, Guannel G (2014) Fishery enhancement and coastal protection services provided by two restored Gulf of Mexico oyster reefs. In: Ninan K (ed) Valuing ecosystem servicesmethodological issues and case studies. Edward Elgar, Cheltenham, pp 334-357 464 pp

La Peyre MK, Humphries AT, Casas SM, La Peyre JF (2014) Temporal variation in development of ecosystem services from environmental management oyster reef restoration. Ecol Eng 63:34-44. https://doi.org/10.1016/j.ecoleng.2013.12

La Peyre MK, Serra K, Joyner TA, Humphries A (2015) Assessing shoreline exposure and oyster habitat suitability maximizes potential success for sustainable shoreline protection using restored oyster reefs. PeerJ 3:e1317

Lenihan HS (1999) Physical-biological coupling on oyster reefs: how habitat structure influences individual performance. Ecol Monogr 69:251-275

Liu Q-X, Weerman EJ, Herman PMJ, Olff H, van de Koppel J (2012) Alternative mechanisms alter the emergent properties of self-organization in mussel beds. Proc R Soc B Biol Sci 279:2744-2753

Liu QX, Herman PMJ, Mooij WM, Huisman J, Scheffer M, Olff H, Van de Koppel J (2014) Pattern formation at multiple spatial scales drives the resilience of mussel bed ecosystems. Nat Commun 5:5234. https://doi.org/10.1038/ncomms6234

Lowe RJ, Hart C, Pattiaratchi CB (2010) Morphological constraints to wave-driven circulation in coastal reef-lagoon systems: a numerical study. J Geophys Res 115:C09021. https://doi. org/10.1029/2009JC005753 
Lunt J, Reustle J, Smee DL (2017) Wave energy and flow reduce the abundance and size of benthic species on oyster reefs. Mar Ecol Prog Ser 569:25-36

Manis JE, Garvis SK, Jachec SM, Walters LJ (2015) Wave attenuation experiments over living shorelines over time: a wave tank study to assess recreational boating pressures. J Coast Conserv 19:1-11

Mann R, Powell EN (2007) Why oyster restoration goals in the Chesapeake Bay are not and probably cannot be achieved. J Shellfish Res 26:905-917

Meyer DL, Townsend EC, Thayer GW (1997) Stabilization and erosion control value of oyster cultch for intertidal marsh. Restor Ecol 5:93-99

Monismith SG (2007) Hydrodynamics of coral reefs. Annu Rev Fluid Mech 39:37-55. https://doi. org/10.1146/annurev.fluid.38.050304.092125

Montserrat F, Van Colen C, Provoost P, Milla M, Ponti M, Van den Meersche K, Ysebaert T, Herman PMJ (2009) Sediment segregation by biodiffusing bivalves. Estuar Coast Shelf Sci 83:379-391

Newell RIE (2004) Ecosystem influences of natural and cultivated populations of suspensionfeeding bivalve molluscs: a review. J Shellfish Res 23:51-61

Newell RIE, Koch EW (2004) Modeling seagrass density and distribution in response to changes in turbidity stemming from bivalve filtration and seagrass sediment stabilization. Estuaries 27:793-806

Nienhuis PH, Smaal AC (1994) Oosterschelde estuary (the Netherlands): a case-study of a changing ecosystem. Kluwer Academic Publishers, Dordrecht

Nieuwhof S, van Belzen J, Oteman B, van de Koppel J, Herman PMJ, van der Wal D (2017) Shellfish reefs increase water storage capacity on intertidal flats over extensive spatial scales. Ecosystems. https://doi.org/10.1007/s10021-017-0153-9

Peterson BJ, Heck KL (2001) Positive interactions between suspension-feeding bivalves and seagrass: a facultative mutualism. Mar Ecol Prog Ser 213:143-155

Piazza BP, Banks PD, La Peyre MK (2005) The potential for created oyster shell reefs as a sustainable shoreline protection strategy in Louisiana. Restor Ecol 13:499-506

Powers S, Peterson C, Grabowski J, Lenihan H (2009) Success of constructed oyster reefs in noharvest sanctuaries: implications for restoration. Mar Ecol Prog Ser 389:159-170 http://www. jstor.org/stable/24873610

Quataert E, Storlazzi C, van Rooijen A, Cheriton O, van Dongeren A (2015) The influence of coral reefs and climate change on wave-driven flooding of tropical coastlines. Geophys Res Lett 42:2015GL064861. https://doi.org/10.1002/2015GL064861

Reise K (2002) Sediment mediated species interactions in coastal waters. J Sea Res 48:127-141

Rodriguez AB, Fodrie FJ, Ridge JT, Lindquist NL, Theuerkauf EJ, Coleman SE, Grabowski JH, Brodeur MC, Gittman RK, Keller DA, Kenworthy MD (2014) Oyster reefs can outpace sealevel rise. Nat Clim Chang 4:493-497

Rogers JS, Monismith SG, Feddersen F, Storlazzi CD (2013) Hydrodynamics of spur and groove formations on a coral reef. J Geophys Res Ocean 118:3059-3073. https://doi.org/10.1002/ jgrc. 20225

Scyphers SB, Powers SP, Heck KL, Byron D (2011) Oyster reefs as natural breakwaters mitigate shoreline loss and facilitate fisheries. PLoS One 6:e22396

Scyphers SB, Picou JS, Brumbaugh RD, Powers SP (2014a) Integrating societal perspectives and values for improved stewardship of a coastal ecosystem engineer. Ecol Soc 19(3):38. https:// doi.org/10.5751/ES-06835-190338

Scyphers SB, Powers SP, Heck KL Jr (2014b) Ecological value of submerged breakwaters for habitat enhancement on a residential scale. Environ Manag. https://doi.org/10.1007/ s00267-014-0394-8

Scyphers SB, Powers SP, Heck KL (2015) Ecological value of submerged breakwaters for habitat enhancement on a residential scale. Environ Manag 55:383-391. https://doi.org/10.1007/ s00267-014-0394-8

Sheppard C, Dixon DJ, Gourlay M, Sheppard A, Payet R (2005) Coral mortality increases wave energy reaching shores protected by reef flats: examples from the Seychelles. Estuar Coast Shelf Sci 64:223-234. https://doi.org/10.1016/j.ecss.2005.02.016 
Temmerman S, Meire P, Bouma TJ, Herman PMJ, Ysebaert T, De Vriend HJ (2013) Ecosystembased coastal defence in the face of global change. Nature 504:79-83

Theuerkauf SJ, Eggleston DB, Puckett BJ, Theuerkauf KW (2017) Wave exposure structures oyster distribution on natural intertidal reefs, but not on hardened shorelines. Estuar Coasts 40:376-386

van de Koppel J, Rietkerk M, Dankers N, Herman PMJ (2005) Scale dependent feedback and regular spatial patterns in young mussel beds. Am Nat 165:E66-E77

van de Koppel J, Gascoigne JC, Theraulaz G, Rietkerk M, Mooij WM, Herman PMJ (2008) Experimental evidence for spatial self-organization and its emergent effects in mussel bed ecosystems. Science 322:739-742

van de Koppel J, van der Heide T, Altieri AH, Eriksson BK, Bouma TJ, Olff H, Silliman BR (2015) Long-distance interactions regulate the structure and resilience of coastal ecosystems. Annu Rev Mar Sci 7:139-158

Van der Meer JW, Briganti R, Zanuttigh B, Wang B (2005) Wave transmission and reflection at low-crested structures: design formula, oblique wave attack and spectral change. Coast Eng 52:915-929

Walles B, Salvador De Paiva J, van Prooijen B, Ysebaert T, Smaal A (2015a) The ecosystem engineer Crassostrea gigas affects tidal flat morphology beyond the boundary of their reef structures. Estuar Coasts 38:941-950

Walles B, Mann R, Ysebaert T, Troost K, Herman PMJ, Smaal A (2015b) Demography of the ecosystem engineer Crassostrea gigas, related to vertical reef accretion and reef persistence. Estuar Coast Shelf Sci 154:224-233

Walles B, Troost K, van den Ende D, Nieuwhof S, Smaal AC, Ysebaert T (2016a) From artificial structures to self-sustaining oyster reefs. J Sea Res 108:1-9

Walles B, Smaal AC, Herman PMJ, Ysebaert T (2016b) Niche dimension differs among lifehistory stages of Pacific oysters in intertidal environments. Mar Ecol Prog Ser 562:113-122

Walles B, Fodrie FJ, Nieuwhof S, Jewell OJW, Herman PMJ, Ysebaert T (2016c) Guidelines for evaluating performance of oyster habitat restoration should include tidal emersion: reply to Baggett et al. Restor Ecol 24(1):4-7

Widdows J, Lucas JS, Brinsley MD, Salkeld PN, Staff FJ (2002) Investigation of the effects of current velocity on mussel feeding and mussel bed stability using an annular flume. Helgol Mar Res 56:3-12

Zee E, Heide T, Donadi S, Eklöf J, Eriksson B, Olff H, Veer H, Piersma T (2012) Spatially extended habitat modification by intertidal reef-building bivalves has implications for consumer-resource interactions. Ecosystems 15:664-673

zu Ermgassen P, Hancock B, DeAngelis B, Greene J, Schuster E, Spalding M, Brumbaugh R (2016) Setting objectives for oyster habitat restoration using ecosystem services: a manager's guide. The Nature Conservancy, Arlington. 76pp. Available at http://oceanwealth.org/tools/ oyster-calculator/

Open Access This chapter is licensed under the terms of the Creative Commons Attribution 4.0 International License (http://creativecommons.org/licenses/by/4.0/), which permits use, sharing, adaptation, distribution and reproduction in any medium or format, as long as you give appropriate credit to the original author(s) and the source, provide a link to the Creative Commons license and indicate if changes were made.

The images or other third party material in this chapter are included in the chapter's Creative Commons license, unless indicated otherwise in a credit line to the material. If material is not included in the chapter's Creative Commons license and your intended use is not permitted by statutory regulation or exceeds the permitted use, you will need to obtain permission directly from the copyright holder.

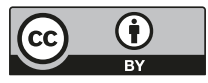

